\title{
Glucose-6-phosphate Dehydrogenase from Agaricus bisporus: Purification and Properties
}

\author{
By JOHN B. W. HAMMOND \\ Glasshouse Crops Research Institute, Worthing Road, Littlehampton, Sussex BN17 6LP, UK
}

(Received 11 May 1984; revised 3 September 1984)

\begin{abstract}
Agaricus bisporus glucose-6-phosphate dehydrogenase (EC 1.1.1.49) was purified to homogeneity. The subunit molecular weight was 55300 and the molecular weight of the native protein was 138000 by gel filtration and 131800 by rate zonal ultracentrifugation on sucrose gradients. There was some evidence for a small population of higher molecular weight oligomers during rate zonal centrifugation. A sedimentation coefficient of $8.5 \mathrm{~S}$ was determined by analytical ultracentrifugation (suggesting the presence of the tetramer). Three bands of enzyme activity were separated on polyacrylamide gels. Digests of the proteins in the three bands gave peptide patterns with no detectable difference after SDS electrophoresis. Linear double reciprocal plots were obtained with glucose 6-phosphate as a variable substrate. The apparent $K_{\mathrm{m}}$ for glucose 6phosphate was $214 \mu \mathrm{M}$ and the $V_{\max }$ was $520 \mu \mathrm{mol}(\mathrm{mg} \text { protein) })^{-1} \mathrm{~min}^{-1}$. A sigmoidal saturation curve and a non-linear double reciprocal plot were observed for NADP, giving a Hill constant of 1.5 and $[\mathrm{S}]_{0.5}$ for NADP of $89 \mu \mathrm{M}$. The enzyme was inhibited by NADPH, with $50 \%$ inhibition at a NADP: NADPH ratio of 0.4 when total NADP $(H)$ concentration was $0.2 \mathrm{~mm}$. ATP, ADP, AMP and cAMP had no effect on enzyme activity. Palmitoyl CoA inhibited the initial velocity of the reaction by $95 \%$ at a concentration of $1.5 \mu \mathrm{M}$ when incubated with enzyme prior to NADP addition.
\end{abstract}

\section{INTRODUCTION}

A significant proportion of hexose oxidation in the cultivated mushroom (Agaricus bisporus) occurs via the pentose phosphate pathway (Le Roux, 1967; Hou et al., 1975; Hammond, 1977). Radiorespirometry and determinations of enzyme activity suggest that the pathway is more active in the fruit body than in the mycelium (Hou et al., 1975; Hammond, 1977). NADPH produced in the operation of the pentose phosphate pathway is used in the synthesis of mannitol, a major component of fruit body dry weight, via the enzyme mannitol dehydrogenase (Edmundowicz \& Wriston, 1963; Dütsch \& Rast, 1972). Stimulation of the pentose phosphate pathway, as measured by extractable activity of glucose-6-phosphate dehydrogenase (G6PD), occurs during the early growth of fruiting 'flushes' and thus may be linked with the initiation of flush growth (Hammond, 1981). Because of the possible importance of G6PD in the fruiting process and the need to understand its regulation, purification and characterization of the enzyme were undertaken.

\section{METHODS}

Enzyme extraction and purification. All operations were carried out at $2{ }^{\circ} \mathrm{C}$. Agaricus bisporus (strain 'Darlington's 649') fruit bodies (approx. $1200 \mathrm{~g}$ fresh wt) were harvested at developmental stage 2 (Hammond \& Nichols, 1976) and homogenized in $500 \mathrm{ml} 100 \mathrm{mM}$-Tris/ $\mathrm{HCl}$ buffer $\mathrm{pH} 7.7$ containing $50 \mathrm{~mm}$-2-mercaptoethanol, 1 mM-EDTA and $0.1 \mathrm{~mm}$-PMSF (buffer 1). The homogenate was centrifuged for $30 \mathrm{~min}$ at $30000 \mathrm{~g}$ and the supernatant decanted and ammonium sulphate added to give $226 \mathrm{~g} \mathrm{l}^{-1}$. The precipitate was removed by centrifugation for $30 \mathrm{~min}$ at $30000 \mathrm{~g}$ and more ammonium sulphate $\left(153 \mathrm{~g} \mathrm{l}^{-1}\right)$ added to the supernatant. The precipitate was

\footnotetext{
Abbreciations: G6P, glucose 6-phosphate; G6PD glucose-6-phosphate dehydrogenase; PMSF, phenylmethyl sulphonyl fluoride.
} 
removed by centrifugation and dissolved in the minimum quantity of buffer 1 . The solution was dialysed overnight against 50 vols of buffer 1 and then applied to a column $(50 \times 50 \mathrm{~mm})$ of Reactive red 120-agarose (Sigma). After washing the column with $400 \mathrm{ml}$ of buffer 1 , G6PD activity was eluted with $8 \mathrm{~mm}$-NADP (10 ml) in buffer 1 , followed by buffer 1 .

The active fractions were pooled and applied to a DEAE Sepharose CL6B column $(26 \times 165 \mathrm{~mm}$; Pharmacia $)$ and equilibrated with $50 \mathrm{~mm}$-Tris/HCl pH 7.2 containing $50 \mathrm{~mm}$-mercaptoethanol, $1 \mathrm{~mm}$-EDTA and $0.1 \mathrm{~mm}$ PMSF (buffer 2). The column was washed with $250 \mathrm{ml}$ buffer 2 and the enzyme eluted with a linear $0-0 \cdot 4 \mathrm{M}-\mathrm{NaCl}$ gradient $(500 \mathrm{ml})$ in buffer 2 . The active fractions were pooled and dialysed against buffer 1 . After dialysis the enzyme preparation was applied to a column $(32 \times 45 \mathrm{~mm})$ of Reactive blue 2-agarose (Sigma) equilibrated with buffer 1 . Enzyme activity was eluted with a linear $0-2.5 \mathrm{M}-\mathrm{NaCl}$ gradient in buffer 1 . The active fractions were concentrated in an Amicon ultrafiltration cell with PM10 membrane at $103.5 \mathrm{kPa}$ nitrogen, and then dialysed against buffer 1 without EDTA or PMSF.

G6PD assay. The assay solution contained 0.22 mM NADP; 3 mM-glucose 6-phosphate (G6P); $100 \mu$ l enzyme sample and $100 \mathrm{~mm}$-Tris/ $\mathrm{HCl}$ buffer $\mathrm{pH} 7 \cdot 4$, with $50 \mathrm{~mm}-2$-mercaptoethanol in a total volume of $1.3 \mathrm{ml}$. The reaction was started by addition of G6P. In the kinetics experiments, pure enzyme ( $430 \mathrm{ng}$ ) was used and NADP and G6P concentrations were varied as shown in Results. Palmitoyl CoA was added to the enzyme/buffer mixture in the quantities given and incubated for $5 \mathrm{~min}$ at room temperature before enzyme assay. The reaction was started by addition of G6P and NADP together. Progress was monitored by measuring absorbance at $340 \mathrm{~nm}$. Initial reaction rates were measured from the initial, linear part of the chart readout. Incubation was at $30^{\circ} \mathrm{C}$. Units of enzyme activity were defined as $\mu$ mol NADP reduced $\min ^{-1}$, under the above conditions, calculated using a molar absorbance value of $6200 \mathrm{M}^{-1} \mathrm{~cm}^{-1}$ for NADPH. Protein was assayed by the method of Lowry or the dye-binding assay of Bradford (1976).

Alcohol dehydrogenase assay. The assay solution contained $0.22 \mathrm{mM} \mathrm{NAD,} 100 \mathrm{~mm}$-ethanol and $100 \mu \mathrm{l}$ enzyme sample in $100 \mathrm{~mm}$-Tris $/ \mathrm{HCl}$ buffer $\mathrm{pH} 7.7$ in a total volume of $1.3 \mathrm{ml}$. The reaction was started by addition of ethanol, and progress monitored by measuring absorbance at $340 \mathrm{~nm}$.

$P A G E$. Disc electrophoresis of native proteins was carried out in $5 \%$ gels at $\mathrm{pH} 8.9$ as described by Davis (1964) omitting spacer and small pore gels. Protein was stained with Coomassie blue R250. G6PD was localized by incubating gels at $35^{\circ} \mathrm{C}$ in a solution containing $12.5 \mathrm{mg} \mathrm{G6P,} 3 \mathrm{mg}$ NADP, $3.5 \mathrm{mg}$ nitro blue tetrazolium and $0.25 \mathrm{mg}$ phenazine methosulphate in $10 \mathrm{ml} 100 \mathrm{~mm}$-Tris/ $\mathrm{HCl}$ buffer $\mathrm{pH} 7.4$. SDS-PAGE was carried out by the method of Weber \& Osborne (1969). Molecular weight standards used were BSA (66000), ovalbumin (43000), trypsin (23500) and myoglobin (17200).

Peptide mapping. Sections of native gel containing the separated isozymes were cut out after Coomassie blue staining, digested with $\mathrm{N}$-chlorosuccinimide/urea and run on an SDS polyacrylamide slab gel as described by Lischwe \& Ochs (1982). The peptides were silver stained (Wray et al., 1981).

Rate zonal centrifugation. Sample $(0.2 \mathrm{ml})$ was layered on top of a $10-40 \%$ sucrose gradient $(3.8 \mathrm{ml})$ in buffer 1 and the tubes centrifuged in a Beckman L8-55 ultracentrifuge with SW60Ti rotor for $24 \mathrm{~h}$ at 55000 r.p.m. The gradients were fractionated $(0 \cdot 2 \mathrm{ml}$ per fraction) and activity of G6PD and an alcohol dehydrogenase standard assayed. Protein content was determined by measuring absorbance at $280 \mathrm{~nm}$. The molecular weight of G6PD was calculated according to Martin \& Ames (1961).

Gel filtration. This was carried out on a column $(16 \times 580 \mathrm{~mm})$ of Sephacryl S-300 (Pharmacia), equilibrated with buffer 1. Blue dextran (Pharmacia) was used to determine void volume. Molecular weight standards were alcohol dehydrogenase (150000), BSA (66000) and trypsin (23500).

Analytical ultracentrifugation. Samples of purified enzyme $\left(1 \mathrm{mg} \mathrm{m}^{-1}\right)$ in buffer 1 without EDTA and PMSF were centrifuged in a synthetic boundary cell, and the sedimentation coefficient obtained by the graphical method of Markham (1960).

Antibody production. Rabbit antibody was raised with purified enzyme as described by Wood (1980). Blood was centrifuged for $10 \mathrm{~min}$ at $30000 \mathrm{~g}$ and the supernatant antiserum used without further treatment. The antiserum was checked by double immunodiffusion (Ouchterlony, 1949), and found to give a single precipitin band at $1: 16$ dilution against $1 \mathrm{mg}$ pure enzyme $\mathrm{ml}^{-1}$.

Fused rocket immunoelectrophoresis. This was carried out according to Axelsen et al. (1973). Samples (15 $\mu 1)$ of the fractions from rate zonal centrifugation were applied to adjacent wells punched in a sample gel of $1 \%$ agarose in $100 \mathrm{~mm}$-Tris/barbiturate buffer $\mathrm{pH} \mathrm{8.6}$. Diffusion was allowed to take place for $1 \mathrm{~h}$ at room temperature. The sample gel was then removed from the supporting plate to within $10 \mathrm{~mm}$ of the sample wells and antiserum containing gel $(35 \mu \mathrm{l}$ antiserum/12 $\mathrm{ml}$ agarose gel) cast in its place. The sample was then electrophoresed into the antibody-containing gel overnight at $2 \mathrm{~V} \mathrm{~cm}^{-1}$, with cooling, using an LKB Multiphor flat bed electrophoresis apparatus. Gels were pressed, washed with $0.9 \% \mathrm{NaCl}$ for $30 \mathrm{~min}$, pressed and dried before staining with Coomassie blue R250:

Isoelectric point. This was determined by isoelectric focusing at $10^{\circ} \mathrm{C}$ in a pre-prepared polyacrylamide gel slab containing ampholytes for the $\mathrm{pH}$ range 3.5-9 (LKB PAG-plate). Calibration of the $\mathrm{pH}$ gradient was by a standard protein calibration mixture (Pharmacia). The gel was stained as described above. 
Table 1. Purification procedure for A. bisporus G6PD. Data from a typical preparation

\begin{tabular}{|c|c|c|c|c|c|c|}
\hline & $\begin{array}{l}\text { Volume } \\
\text { (ml) }\end{array}$ & $\begin{array}{c}\text { Activity } \\
\text { (units } \mathrm{ml}^{-1} \text { ) }\end{array}$ & $\begin{array}{c}\text { Protein } \\
\text { content } \\
\left(\mathrm{mg} \mathrm{ml}^{-1}\right)\end{array}$ & $\begin{array}{c}\text { Specific } \\
\text { activity } \\
\text { (units } \mathrm{mg}^{-1} \text { ) }\end{array}$ & $\begin{array}{c}\text { Purification } \\
\text { factor } \\
\text { (fold) }\end{array}$ & $\begin{array}{c}\text { Yield } \\
(\%)\end{array}$ \\
\hline $\begin{array}{l}\text { Crude homogenate } \\
40-65 \% \text { ammonium sulphate }\end{array}$ & 1280 & $1 \cdot 32$ & $4 \cdot 8$ & $0 \cdot 28$ & 0 & 100 \\
\hline fraction & 240 & $8 \cdot 0$ & $14 \cdot 1$ & 0.57 & 2 & 118 \\
\hline Reactive-Red-agarose eluate & 56 & $37 \cdot 7$ & $1 \cdot 2$ & $31 \cdot 4$ & 114 & 130 \\
\hline DEAE-sepharose eluate & 52 & $35 \cdot 6$ & $0 \cdot 16$ & 230 & 831 & 114 \\
\hline Reactive Blue-agarose eluate & 72 & $9 \cdot 4$ & 0.033 & 288 & 1040 & 42 \\
\hline Final concentrate & $2 \cdot 8$ & $177 \cdot 4$ & $0 \cdot 62$ & 287 & 1037 & 31 \\
\hline
\end{tabular}

\section{RESULTS}

Enzyme purification. The results of a typical purification are shown in Table 1. The apparent increase in activity at the ammonium sulphate and Reactive red steps may be due to removal of interfering material, or activation of inactive enzyme present in the homogenate. The active pool from the Reactive blue- 2 agarose column gave a single protein band after SDS-PAGE of samples containing up to $30 \mu \mathrm{g}$ protein. The specific activity of final preparations ranged between 280 and 330 units (mg protein) $)^{-1}$; these values are comparable with those for purified G6PD from other eukaryotes (e.g. Noltmann et al., 1961; Engel et al., 1969; Donohue et al., 1981).

Multiple forms of G6PD. The purified enzyme showed three protein staining bands (A, B, C in order of speed of migration), with corresponding activity bands after PAGE of the native protein. Examination of the gels with a scanning densitometer showed that band $\mathrm{C}$ contained about $20 \%$ more protein than band A, and band B was intermediate. Densitometry of the activity stained gels and comparison of the data with that from protein stained gels suggested that the specific activity of the fastest moving band (A) may have been about $15 \%$ greater than that of the other two.

Digestion of the separated bands with $N$-chlorosuccinimide/urea followed by SDS-PAGE showed 18 detectable peptides with molecular weights from approximately 12000 to 60000 . No difference could be detected between the peptide patterns obtained from the three different bands.

Molecular weight. The subunit molecular weight of the enzyme, determined by SDS-PAGE was 55360. Rate zonal ultracentrifugation of dilute $\left(40 \mu \mathrm{g} \mathrm{ml}^{-1}\right)$ or concentrated $\left(1 \mathrm{mg} \mathrm{m}^{-1}\right)$ purified enzyme on a sucrose gradient resulted in activity profiles with major activity at a mol. wt 131800 . In most preparations there was a small amount of activity near the bottom of the gradient with mol. wt between 250000 and 350000 (Fig. $1 a$ ). Fused rocket immunoelectrophoresis of gradient fractions was carried out to determine whether inactive forms of the enzyme, e.g. monomers, were present, and whether the molecular specific activities of the G6PD peaks were similar (Fig. $1 b$ ). There was no evidence for antigenic material in the lower mol. wt fractions of the gradient, and the fused rocket heights for the 131800 and $250000-350000 \mathrm{~mol}$. wt bands were proportional to the activities in the same fractions. The mol. wt determined by gel filtration on Sephacryl S-300 was 138000.

The effect of the presence of NADP and G6P on the aggregation state of the G6PD molecule was tested by carrying out rate zonal ultracentrifugation in the presence of $15 \mu \mathrm{M}$ - or $150 \mu \mathrm{M}$ NADP or $1 \mathrm{~mm}-\mathrm{G} 6 \mathrm{P}$. There was no change in either activity or enzyme protein distribution on the gradient as a result of these treatments, in the presence or absence of $1 \mathrm{mM}$-EDTA. The pure enzyme $\left(0 \cdot 8-1 \mathrm{mg} \mathrm{ml}^{-1}\right)$ from three different preparations sedimented as a single species of sedimentation coefficient $\left(s_{20, w}\right) 8 \cdot 5 \mathrm{~S}$.

Isoelectric point and pH optimum. The $\mathrm{pI}$ as determined at $10{ }^{\circ} \mathrm{C}$ by isoelectric focusing on polyacrylamide gel was between 5.9 and 6.05 . The greatest stability of the purified enzyme to 

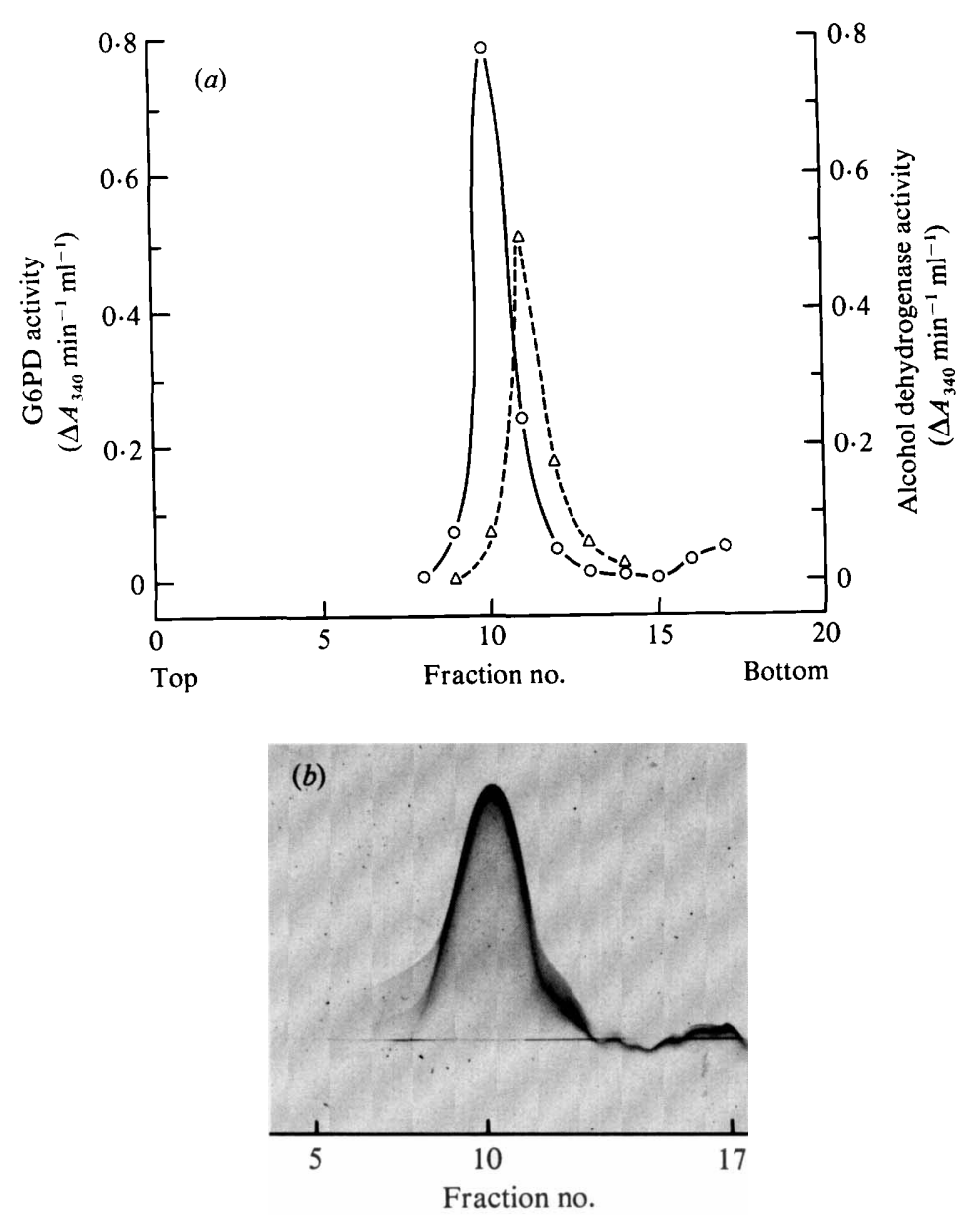

Fig. 1. Sucrose gradient rate zonal ultracentrifugation. (a) G6PD activity in fractions $(\mathrm{O}-\mathrm{O})$, with alcohol dehydrogenase standard $(---) ;(b)$ fused rocket immunoelectrophoresis of gradient fractions.

incubation at $35^{\circ} \mathrm{C}$ for $1 \mathrm{~h}$ was at $\mathrm{pH} 6.5$, but only $30 \%$ less activity was seen after incubation at $\mathrm{pH} 8 \cdot 0$. Optimum enzyme activity was observed at $\mathrm{pH} 7 \cdot 4$ in $\mathrm{Tris} / \mathrm{HCl}$ buffer.

Specificity. No reaction could be observed with NAD at $0 \cdot 22 \mathrm{~mm}$, or with glucose 1-phosphate ( $3 \mathrm{mM}$ ). There was no increase in activity in the presence of $15 \mathrm{mM}-\mathrm{MgCl}_{2}$.

G6PD kinetics. The enzyme gave linear double reciprocal plots with $\mathrm{G} 6 \mathrm{P}$ as variable substrate at five different NADP concentrations between 100 and $750 \mu \mathrm{M}$. Two of the plots are shown in Fig. 2. The apparent $K_{\mathrm{m}}$ value for G6PD, calculated from Eadie-Hofstee plots was $214 \pm 42 \mu \mathrm{M}$. The $V_{\max }$ was $520 \mu \mathrm{mol}(\mathrm{mg} \text { protein })^{-1} \mathrm{~min}^{-1}$.

With NADP as variable substrate, the rate vs substrate concentration plot was sigmoidal. When the data were plotted as $1 / v$ vs $1 /[\mathrm{S}]$, curves were obtained which were concave upwards, suggesting positive co-operativity towards NADP (Fig. 3). A Hill plot of the data at saturating G6P concentration ( $2 \mathrm{mM}$ ) gave a value of 1.5 for the Hill constant, and a [S $]_{0.5}$ for NADP of $89 \mu \mathrm{M}$. The mean value for the Hill constant determined at G6P concentrations between 0.025 and $2 \mathrm{mM}$ was $1 \cdot 68 \pm 0 \cdot 14$ (SE) (seven determinations).

Substrate inhibition was observed at NADP concentrations above $1 \mathrm{mM}$ and G6P concentrations above $2 \mathrm{~mm}$. The effect of enzyme concentration on initial velocity of the reaction was tested over the range $0 \cdot 165-5 \mu \mathrm{g}$ protein $\mathrm{ml}^{-1}$. the resultant plot was linear. 


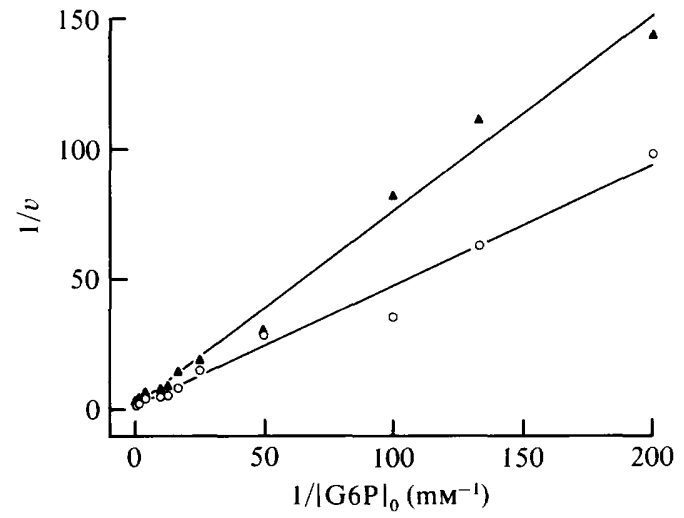

Fig. 2

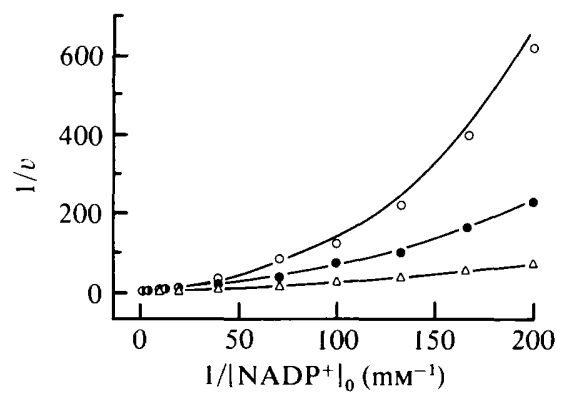

Fig. 3

Fig. 2. Lineweaver-Burk double reciprocal plot of G6PD initial velocity vs G6P concentration at $0.2 \mathrm{mM}(\mathbf{\Delta})$ and $0.75 \mathrm{mM}$ NADP $(\mathbf{O})$.

Fig. 3. Lineweaver-Burk double reciprocal plots of G6PD initial velocity vs NADP concentration at $0.2 \mathrm{~mm}(\mathrm{O})$ and $0.5 \mathrm{mM}(\bigcirc)$; and $2.0 \mathrm{~mm}$ G6P $(\triangle)$.

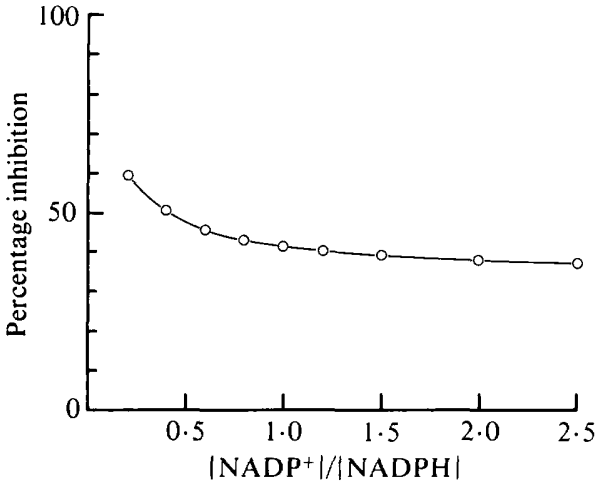

Fig. 4

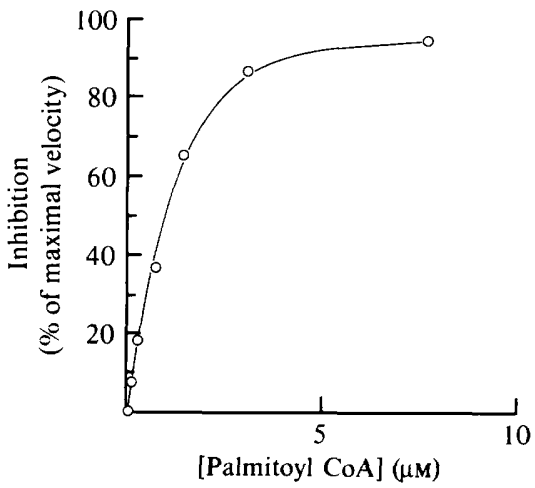

Fig. 5

Fig. 4. Influence on initial velocity of G6PD reaction of varying NADP:NADPH ratio at constant $(0.2 \mathrm{~mm})$ NADP + NADPH concentration. G6P concentration, $4 \mathrm{~mm}$.

Fig. 5. Effect of palmitoyl CoA concentration on maximal velocity of G6PD reaction.

Inhibitors. The forward reaction was inhibited by NADPH. Inhibition at a range of NADP:NADPH ratios and constant NADP + NADPH of $0.2 \mathrm{~mm}$ was tested. Inhibition was relatively constant at about $40 \%$ at NADP:NADPH ratios between 0.75 and 2.5 , but increased to $60 \%$ at a ratio of 0.2 (Fig. 4). No inhibition was observed with ATP at concentrations up to $1 \mathrm{mM}$, nor was there any effect of ADP or AMP $(1 \mathrm{mM})$ or cAMP $(100 \mu \mathrm{M})$.

When pre-incubated with palmitoyl CoA in the absence of NADP, the enzyme was strongly inhibited. A lag phase of 1-2 minutes was observed after addition of substrate and NADP before maximal reaction velocity was reached. Inhibition of $95 \%$ was observed with $1.5 \mu \mathrm{M}$ palmitoyl CoA when calculated from initial velocity measurements. Using maximal velocity measurements, $50 \%$ inhibition was achieved at $1 \mu \mathrm{M}$ palmitoyl CoA (Fig. 5). When NADP $(0.75 \mathrm{mM})$ was added before pre-incubation with palmitoyl CoA, the inhibition was reduced, $70 \%$ inhibition of initial velocity being observed with $1.5 \mu \mathrm{M}$ palmitoyl CoA. Addition of G6P $(1 \mathrm{mM})$ to the preincubation mixture had no effect on the palmitoyl CoA inhibition. When 
G6PD which had been pre-incubated with $10 \mu \mathrm{M}$ palmitoyl CoA was subjected to rate zonal ultracentrifugation on a sucrose gradient containing the inhibitor, sedimentation occurred at a rate which suggested a mol. wt of 138000 with a small amount of activity in the mol. wt range 250000-350000 as observed with the untreated enzyme. When the gradient fractions were analysed by fused rocket immunoelectrophoresis, G6PD protein was found only in those fractions which exhibited activity.

\section{DISCUSSION}

G6PD from A. bisporus appears to be similar in most of its molecular properties to the enzyme from other organisms. The subunit mol. wt of 55400 is similar to that for G6PD from yeast (51000; Yue et al., 1969), rat liver (57000; Donohue et al., 1981) and Bacillus licheniformis (60000; Opheim \& Bernlohr, 1973). Native G6PD from other sources is normally dimeric or tetrameric, with the monomer showing no catalytic activity (Levy, 1979). In most cases the purified enzyme is in the dimeric form, mol. wt 104000-130000 (Levy, 1979). The native mol. wt of $A$. bisporus G6PD was approximately 2.5 times the subunit mol. wt. However, the dimer seems the most likely form; the native mol. wt is within range seen for dimers from other organisms. No trimeric forms of G6PD have been reported. The sedimentation coefficient obtained by analytical ultracentrifugation is consistent with a tetramer of mol. wt approximately 200000 (c.f. Levy, 1979). The reason for this anomaly is not clear. Even at high protein concentrations, the mol. wt determined by rate zonal ultracentrifugation was 132000 , although at both high and low concentrations a small amount of higher mol. wt enzyme was found. Electrophoresis of native enzyme on polyacrylamide gradient gels gave varying results, but suggested that higher oligomers were present as well as the dimer (results not shown). It is possible that the enzyme is present as a dimer at low protein concentrations and as a tetramer at high concentrations, but that tetramer formation is inhibited by the sucrose present in the density gradient. Sucrose inhibition of aggregation has been observed with glutamate dehydrogenase (Yielding, 1970), but significant tetramer formation by G6PD has been observed on sucrose gradients (Muto \& Uritani, 1971; Bonsignore et al., 1971). Despite this uncertainty with regard to the aggregation state of G6PD in vivo, it seems unlikely that aggregation of the dimer would cause a change in enzyme activity, since the rate zonal data suggest that the molecular specific activity of the enzyme is not changed by formation of higher oligomers.

Changes in G6PD aggregation state between monomer, dimer and tetramer are promoted by NADP and G6P or NADPH in human erythrocytes (Bonsignore et al., 1971), brewer's yeast (Yue et al., 1969), and sweet potato (Muto \& Uritani, 1971). In the yeast, tetramerization is prevented by EDTA. The evidence from rate zonal ultracentrifugation suggests that $A$. bisporus G6PD aggregation is unaffected by NADP or G6P, with or without EDTA.

The occurrence of three bands of G6PD activity on polyacrylamide gels could be due to limited proteolytic activity during extraction, or to the presence of multiple forms of the enzyme in vivo. Proteolysis of the enzyme seems unlikely since the relative levels of the three bands were similar in several preparations in the presence and absence of PMSF, and because of the similarity in molecular specific activity of the three forms as assessed from protein and activity stains on the gels. The three forms were not separated by techniques other than PAGE, unlike the G6PD isozymes from Aspergillus oryzae (Cebrián-Perez et al., 1980) or Candida utilis (Engel et al., 1969). This suggests that they are similar in structure and origin. This conclusion is reinforced by the lack of detectable difference between the peptides derived from the multiple forms by proteolysis. Thus it seems unlikely that the three bands are different gene products but they may be due to different aggregation states (c.f. Bonsignore et al., 1971).

The kinetic properties of G6PD from $A$. bisporus show a general similarity to those of the enzyme from other organisms. The apparent $K_{\mathrm{m}}$ for G6P is within the range reported for other fungi, and the $[\mathrm{S}]_{0.5}$ for NADP is similar to the $K_{\mathrm{m}}$ values from other organisms (Levy, 1979). Sigmoidal saturation curves for NADP have been observed with only a few examples of G6PD, such as mung bean (Ashihara \& Komamine, 1974) and human erythrocyte (Luzzato, 1967). This type of saturation curve may be due to aggregation of the enzyme to a more active oligomer in 
the presence of the substrate (Kurganov, 1982). Sigmoidal saturation curves have also been attributed to the use of Tris/borate buffer (Levy, 1979). The linear rate vs enzyme concentration plot suggests that aggregation to a more active oligomer does not occur at enzyme concentrations up to 15 times greater than those used in the kinetic assays. Since NADP does not appear to have an aggregating effect on the enzyme molecule, the sigmoidal saturation curve with NADP is likely to be due to an allosteric conformation change. The level of inhibition by NADPH at a similar total NADP $(\mathrm{H})$ concentration to those estimated to be present in vivo (Hammond, 1985) was similar to that observed for the rat liver enzyme (Eggleston \& Krebs, 1974). Rat liver G6PD is thought to be almost totally inhibited by NADPH in vivo because of the low free NADP:NADPH ratio (Veech et al., 1969). The activity of the liver enzyme may then be controlled by de-inhibition with GSSG (Eggleston \& Krebs, 1974), although this conclusion has recently been challenged (Levy \& Christoff, 1983). The NADP:NADPH ratio determined for $\boldsymbol{A}$. bisporus suggests that such a mechanism does not occur here, unless there is significant reduction of the ratio by binding of NADP in a form unavailable to the enzyme.

The potent inhibitory effect of palmitoyl CoA has been observed with G6PD from other sources (Taketa \& Pogell, 1966), but the A. bisporus enzyme is more sensitive than that of other micro-organisms tested (Kawaguchi \& Bloch, 1974). The effect on the A. bisporus G6PD molecule also appears to be different to that on the enzyme from baker's yeast and Torulopsis utilis. Palmitoyl CoA caused dissociation of tetramers to dimers in baker's yeast, and of dimers to inactive monomers in T. utilis (Kawaguchi \& Bloch, 1974), but no comparable dissociation was seen in G6PD from $A$. bisporus during rate zonal ultracentrifugation. Regulation of G6PD by palmitoyl CoA in vivo has been suggested for sea urchin eggs (Mita \& Yasumasu, 1980), and it is possible that G6PD activity could be linked to fatty acid synthesis in this way in $A$. bisporus.

A. bisporus G6PD exhibits properties which offer potential for fine regulation of activity in vivo. Control by palmitoyl $\mathrm{CoA}$ inhibition and perhaps by removal of NADPH inhibition is possible, and would allow G6PD activity and pentose phosphate pathway flux to be controlled by the metabolic state of the cell. Control of enzyme activity by allosteric regulation of NADP binding may occur. The large variations in extracted G6PD activity occurring with fruiting (Hammond, 1981) suggest that control of enzyme maximal activity is also important.

The author wishes to thank Drs A. A. Brunt and R. Barton of GCRI Virology Dept for carrying out analytical ultracentrifugation and antibody preparation, respectively, and $\mathrm{Dr}$ M. Partis for advice on peptide mapping.

\section{REFERENCES}

Ashihara, H. \& Komamine, A. (1974). Regulation of the activities of some enzymes of the pentose phosphate pathway in Phaseolus mungo. Zeitschrift für Pflanzenphysiologie 74, 130-142.

Axelsen, N. H., Kroll, J. \& WeEke, B. (1973). A Manual of Quantitive Electrophoresis. Oslo: Universitetsforlaget.

Bonsignore, A., Cancedda, R., Nicolini, A., DAMIANI, G. \& DeFlora, A. (1971). Metabolism of human erythrocyte glucose-6-phosphate dehydrogenase. VI Interconversion of multiple molecular forms. Archives of Biochemistry and Biophysics 147, 493-501.

BRADFORD, M. (1976). A rapid and sensitive method for the quantitation of microgram quantities of protein using the principle of protein-dye binding. Analytical Biochemistry 71, 248-254.

Cebrián-Perez, J. A., Garcia-Gimeno, M. A. \& Muino-BlanCo, T. (1980). Isoenzimas de la glucosa6-fosfato deshidrogenasa de Aspergillus oryzae (Ahlburg). Revista española de fisiologia 36, 389-394.
DAvis, B. J. (1964). Disc electrophoresis. II Method and applications to human serum proteins. Annals of the New York Academy of Sciences 121, 404-427.

Donohue, T. M., Mahowald, T. A., Adams, D. J. \& BARKER, K. L. (1981). Glucose-6-phosphate dehydrogenase. Partial characterization of the rat liver and uterine enzymes. Biochimica et biophysica acta 658, 356-368.

Dü TSCH, G. A. \& RAST, D. (1972). Biochemische Beziehung zwischen Mannitbildung und Hexosemonophosphatzyklus in Agaricus bisporus. Phytochemistry 11, 2677-2681.

Edmundowicz, J. M. \& Wriston, J. C., JR (1963). Mannitol dehydrogenase from Agaricus campestris. Journal of Biological Chemistry 238, 3539-3541.

Eggleston, L. V. \& Krebs, H. A. (1974). Regulation of the pentose phosphate cycle. Biochemical Journal 138, 425-435.

Engel, H. J., Domschke, W., Alberti, M. \& DomaGK, G. F. (1969). Protein structure and enzymatic activity. II Purification and properties of 
a crystalline glucose-6-phosphate dehydrogenase from Candida utilis. Biochimica et biophysica acta 191, 509-516.

Hammond, J. B. W. (1977). Carbohydrate metabolism in Agaricus bisporus: oxidative pathways in mycelium and sporophore. Journal of General Microbiology 102, 245-248.

Hammond, J. B. W. (1981). Variations in enzyme activity during periodic fruiting of Agaricus bisporus. New Phytologist 89, 419-428.

HAMMOND, J. B. W. (1985). Sugar, sugar phosphate and NADP $(\mathrm{H})$ levels in Agaricus bisporus fruit bodies. Journal of General Microbiology 131, 329-333.

Hammond, J. B. W. \& Nichols, R. (1976). Carbohydrate metabolism in Agaricus bisporus (Lange) Sing.: changes in soluble carbohydrates during growth of mycelium and sporophore. Journal of General Microbiology 93, 309-320.

Hou, H. H., Wu, L. C. \& Chen, C. C. (1975). Respiratory pathways of the cultivated mushroom, Agaricus bisporus. Mushroom Science 9, 37-49.

KaWAGUCHI, A. \& BLOCH, K. (1974). Inhibition of glucose 6-phosphate dehydrogenase by palmitoyl CoA. Journal of Biological Chemistry 249, 5793-5800.

Kurganov, B. I. (1982). Allosteric Enzymes - Kinetic Behaviour. Chichester, UK: John Wiley \& Sons.

LE RouX, P. (1967). Importance relative de la voie des pentoses phosphates et de la glycolyse dans le carpophore d'Agaricus bisporus. Annales de Physiologie tégetale 9, 349-363.

LEVY, H. R. (1979). Glucose-6-phosphate dehydrogenases. Advances in Enzymology 48, 97-192.

LeVy, H. R. \& ChristofF, M. (1983). A critical appraisal of the effect of oxidized glutathione on hepatic glucose-6-phosphate dehydrogenase activity. Biochemical Journal 214, 959-965.

Lischwe, M. A. \& OCHS, D. (1982). A new method for partial peptide mapping using $N$-chlorosuccinimide/urea and peptide silver staining in sodium dodecyl sulfate-polyacrylamide gels. Analytical Biochemistry 127, 453-457.

Luzzato, L. (1967). Regulation of the activity of glucose-6-phosphate dehydrogenase by NADP and NADPH. Biochimica et biophysica acta 146, 18-25.

MARKHAM, R. (1960). A graphical method for the rapid determination of sedimentation coefficients. Biochemical Journal 77, 516-519.

Martin, R. A. \& Ames, B. N. (1961). A method for determining the sedimentation behaviour of enzymes. Application to protein mixtures. Journal of Biological Chemistry 236, 1372-1379.
Mita, M. \& Yasumasu, I. (1980). Inhibition of glucose6-phosphate dehydrogenase and 6-phosphogluconate dehydrogenase in sea urchin eggs by palmitoyl coenzyme A and reversal by polyamines. Archives of Biochemistry and Biophysics 201, 322-329.

Muto, S. \& URITANI, I. (1971). Effect of NADP and glucose-6-phosphate on the sedimentation behaviour of glucose-6-phosphate dehydrogenase from sweet potato. Plant and Cell Physiology 12, 803-806.

Noltmann, E. A., Gubler, C. J. \& Kuby, S. A. (1961). Glucose 6-phosphate dehydrogenase (Zwischenferment). 1. Isolation of the crystalline enzyme from yeast. Journal of Biological Chemistry 236, 12251230.

Opheim, D. \& Bernlohr, R. W. (1973). Purification and regulation of glucose-6-phosphate dehydrogenase from Bacillus licheniformis. Journal of Bacteriology 116, 1150-1159.

OUCHTERLONY, O. (1949). Antigen-antibody reactions in gels. Acta pathologica et microbiologica scandinavica 26, 507-515.

Taketa, K. \& Pogell, B. M. (1966). The effect of palmitoyl coenzyme A on glucose-6-phosphate dehydrogenase and other enzymes. Journal of Biological Chemistry 241, 720-726.

Veech, R. L., EgGleston, L. V. \& Krebs, H. A. (1969). The redox state of free nicotinamide adenine dinucleotide phosphate in the cytoplasm of rat liver. Biochemical Journal 115, 609-619.

Weber, K. \& Osborne, M. (1969). Reliability of molecular weight determinations by dodecyl sulfatepolyacrylamide-gel electrophoresis. Journal of Biological Chemistry 244, 4406-4412.

WOOD, D. A. (1980). Production, purification and properties of extracellular laccase of Agaricus bisporus. Journal of General Microbiology 117, 327338.

Wray, W., Boulikas, T., Wray, V. P. \& HaNCOCK, R. (1981). Silver staining of proteins in polyacrylamide gels. Analytical Biochemistry 118, 197-203.

YIELDING, K. L. (1970). Modification by sucrose of the catalytic activity and physical properties of glutamic dehydrogenase. Biophysical and Biochemical Research Communications 38, 546-551.

Yue, R. H., Noltmann, E. A. \& Kuby, S. A. (1969). Glucose-6-phosphate dehydrogenase from brewer's yeast (zwischenferment). III Studies on the subunit structure and on the molecular association phenomenon induced by triphosphoryridine nucleotide. Journal of Biological Chemistry 244, 13531364. 